GOSPODARKA SUROWCAMI MINERALNYMI - MINERAL RESOURCES MANAGEMENT

$2015 \quad$ Volume $31 \quad$ Issue $4 \quad$ Pages $75-94$

DOI 10.1515/gospo-2015-0033

\title{
Structural-textural nature and sorption properties of limestones from the mesozoic-neogene contact zone in the Bełchatów deposit
}

\begin{abstract}
Introduction
In the $21^{\text {st }}$ century, both the development and functioning of the economy will still be based on the use of natural raw materials. Poland is a serious manufacturer of many of them, first of all of coal and copper, but also others, including:sulfur, salt, limestones or sands and gravels. According to the latest data of the Mineral and Energy Economy Research Institute of the Polish Academy of Sciences from 2012 (Smakowski et al. ed. 2014) a declining trend of the production of many of them is being observed. The raw materials, of which production decreased significantly, meaningover $10 \%$ include limestones, while the largest decline - over $23 \%$ - was recorded in the group of limestones exploited for the purpose of the lime industry. These are limestones showing the highest quality, measured by the $\mathrm{CaCO}_{3}$ content. One of the main recipients of this type of raw material is the energy industry based on national coal. In connection with the implementation of the stringent standards of $\mathrm{SO}_{2}$ emission, which forced the implementation of advanced technologies of flue gas desulfurization (FGD) based on carbonate sorbents, the demand for high quality limestones is gradually increasing from year to year. Increasing the supply of raw materials of this type is becoming necessary. Technological descriptions of desulphurisation processes show that sorbent consumption by one of the largest hard-coal-fired domestic power plants and applying the wet method of flue gas desulfurization/FGD is approx. 25 tonnes/hour,
\end{abstract}

* Ph.D. Eng., AGH University of Science and Technology, Krakow, Poland; e-mail: hycnar@geol.agh.edu.pl 
assuming that the year-long operation of the power plant requires deliveries of over 219 thousand tonnes of the sorbent with a particle size distribution below $65 \mu \mathrm{m}$ (of limestone powder). In order to produce such an amount of limestone powder one would need to convert approximately 280 thousand tonnes of limestone, which is the order of magnitude of the total annual extraction in the case of the Góra Maćkowa deposit or almost $14 \%$ of the annual extraction in the Czatkowice deposit (assuming that the yield of the fraction below $63 \mu \mathrm{m}$ from 1 extracted tonne of limestone will constitute 79\%). Despite this, Poland has numerous and rich deposits of high-quality limestones (documented for the needs of the lime industry), however, their intensive exploitation can lead to the rapid depletion of such resources. There is the opportunity for increasing the limestone resource base in led for over 30 years opencast mining of lignite in the Bełchatów region, where one of the most important accompanying minerals are limestones.

\section{Bełchatów limestones}

The Bełchatów lignite deposit is situated on the rift fault trough of Kleszczów, formed in the Mesozoic sediments, Jurassic-Cretaceous limestones and marls. The shores of the rift fault create slopes of exploitation fields in Bełchatów and Szczerców. They are gradually being exposed as a result of the progressive coal exploitation. In order to ensure the stability of slopes during extraction, necessary is modeled to the desired inclination. This is indispensable in this case limestones exploitation, which must be preceded by a detailed recognition and documentation of the geological conditions of the deposit, physico-mechanical parameters and extraction technology design. Limestones are a monolithic rock, not suitable for mining with basic machines working in strip mines, therefore their presence increases the costs of functioning of the Bełchatów Mine in a significant manner. Already in the 1960s, at the stage of exploration of the deposit the tests that were taken aimed at an indication of possible directions of their utilization. In Geological Documentation of the Lignite Bełchatów Deposit (1964) limestones, generally, were recognized as useless for development. It was marked to show that it is possible to get the raw material of use for the needs of the cement industry and for the manufacture of agricultural limestone/soil lime from some lots with the application of selective exploitation. Nevertheless, surveys were continued in areas, where the necessity of forming the slopes at significant sections was predicted. In subsequent Comprehensive Geological Documentations of the Lignite Bełchatów Deposit - Szczerców Field (1977) and Bełchatów Field (1983) and in subsequent appendices to both documentations (Appendix in Cat. B... 1975; Appendix... 1989; Appendix No. 1... 1989; Field Szczerców 2009, 2009a; Field Bełchatów... 2011) indicated areas of the limestones occurrence with beneficial physical and chemical parameters, possible for management in the cement industry, metallurgical industry, for the production of burnt limericultural limestone and highway aggregate.

The Bełchatów limestones have been selectively exploited since 1995 . The only form of their management was and is the production of highway aggregate, mainly for the needs of 
the mine for the construction of haulage roads and local roads. So far about 2 million tonnes of limestones (Adamczyk et al. 2012) have been extracted and managed in the Lignite Bełchatów Mine. Further exploitation of these rocks in significant quantities will be necessary for the purpose of extracting lignite balance resources . It is expected that approx. 2 million tonnes of limestones remains to be extracted from the Bełchatów Field, and from 20 to almost 70 million tonnes (Adamczyk et al. 2012) in the Szczerców Field, depending on the variant of shaping of the excavation contour. In such a situation it became necessary to create new directions of economic utilization of the Bełchatów limestones, which have not yet been taken into account. Actions have been taken in order to determine their usabilities for the production of limestone powder for flue gas desulphurisation process needs in the nearby Bełchatów power plant. The lots of limestones occurring in the parts of upper surface of the complex of bedrocks, being in a direct contact with Neogene sediments turned out to be problematic or even impossible for management.

\subsection{The mineralogical and petrographic nature}

Limestones occurring in the area of the exploitative Szczerców Field are rocks mostly of white color, with massive and solid texture. According to the Folk classification, one should determine them as allochemical microcrystalline limestones. The primary role of rock-forming play in their case sponges, bryozoans, echinoderms or foraminifera, to a lesser extent. Apart from bioclasts, intraclasts and ooliths are also an important ingredient of limestones. The content of allochemical ingredients is differentiated, within the range of 10 to $40 \%$ of rock volume. Their nature allows investigated limestones such as biomicrites, biointramicrites and bioomicrites to be classified (Hycnar et al. 2007).

Roof lots of limestones, occurring in the immediate vicinity with Neogene sediments, in the so-called contact zone possesses properties of a different mineralogical and petrographic nature. They are characterized by strong rubble, karstification, the presence of numerous caverns filled with clay or even occurrence in the form of detrital minerals. Apart from that, they are covered by processes of secondary mineralization. The effect of these processes are of a strongly porous texture (Phot. 1) and the varied in mineral and chemical composition, which translates into lower levels of $\mathrm{CaCO}_{3}$.

The porous texture occurring in the tested limestones is primarily the result of activity of karst solutions, rich in $\mathrm{CO}_{2}$ resulting from the decomposition of organic matter. The observed pores are both intergranular, e.g. between ooliths in bioomicrites, and intragranular (internal particle size distribution), e.g. within the bioclasts or calcitic sparite crystals. A significant porosity also shows microcrystalline rock matrix (Phot. 2). In this case, the occurrence of pores between individual crystals of micrite or microsparite can also be the result of grain dissolution of the crystals.

A common feature of tested limestones is their presence in tectonics discontinuities, known as stylolite seams, as well as cracks and compaction slits. In the limestones from the 


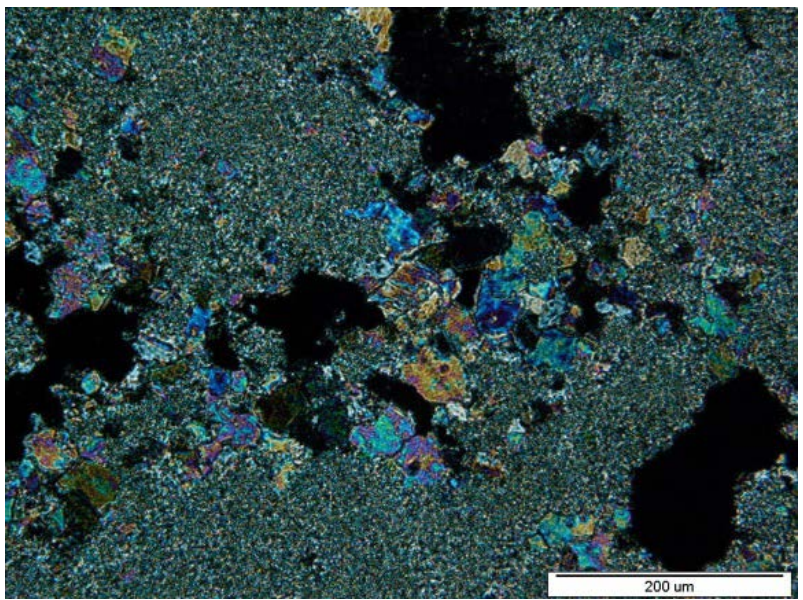

Phot. 1. The limestone from the zone of Mesozoic-Neogene contact in Bełchatów deposit. The porous texture. Polarizing microscope, $\mathrm{Xp}$

Fot. 1. Wapienie ze strefy kontaktu mezozoik-neogen w złożu Bełchatów. Tekstura porowata. Mikroskop polaryzacyjny; Xp

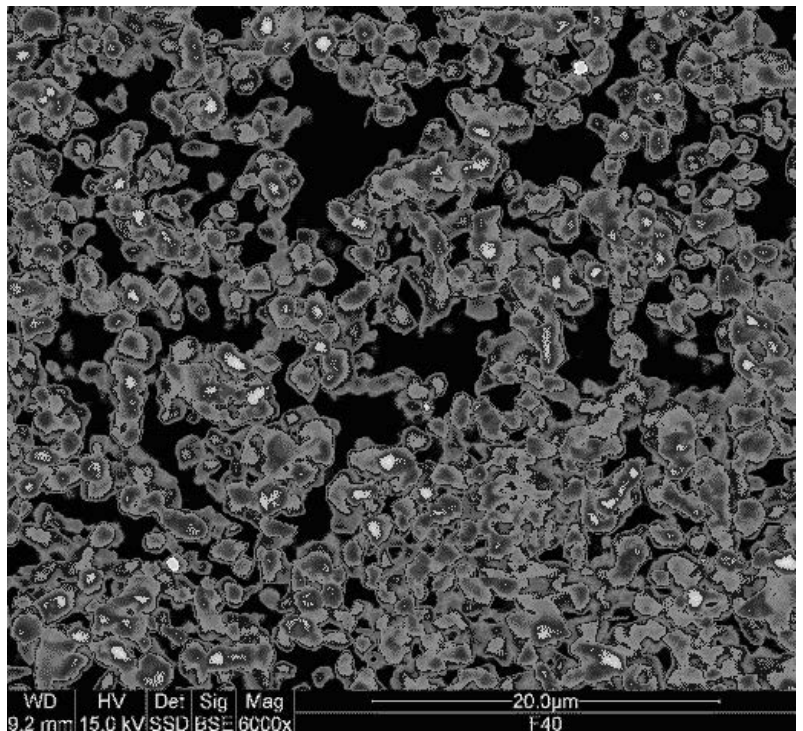

Phot. 2. The limestone from the zone of Mesozoic-Neogene contact in Bełchatów deposit. Porous microcrystalline limestone rock background. SEM/EDX

Fot. 2. Wapienie ze strefy kontaktu mezozoik-neogen w złożu Bełchatów. Porowate mikrokrystaliczne tło skalne wapieni. SEM/EDX 


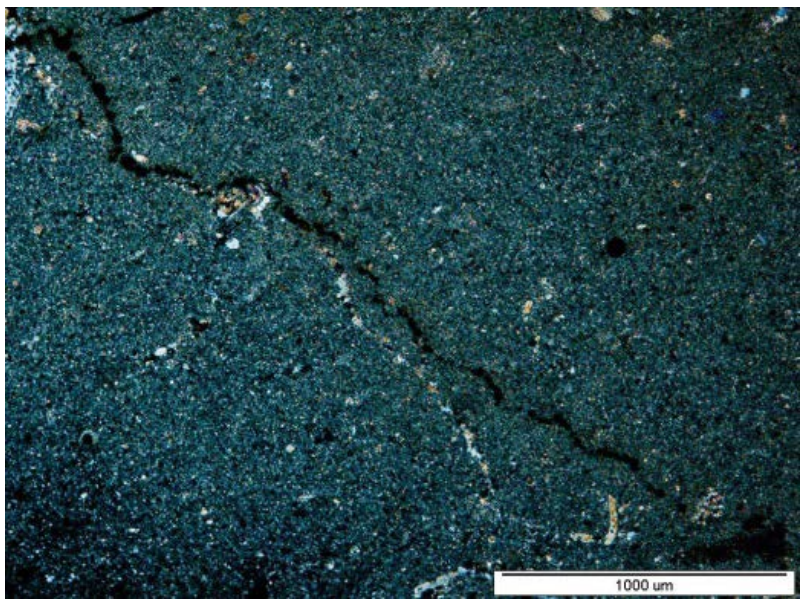

Phot. 3. The limestone from the zone of Mesozoic-Neogene contact in Bełchatów deposit.

The compaction slit pyrite filled. Polarizing microscope, $\mathrm{Xp}$

Fot. 3. Wapienie ze strefy kontaktu mezozoik-neogen w złożu Bełchatów.

Szczelina kompakcyjna wypełniona pirytem. Mikroskop polaryzacyjny; Xp

contact zone, this type of texture elements are filled, mainly, with iron sulfides and an organic substance of vegetable origin (Phot. 3 and 4), to a lesser extent with carbonate cement or silica.

The varied mineral composition of limestones from the described contact zone manifests itself with the presence of a series of mineral phases. Apart from calcite, which remains its principal mineral constituent, minerals from the group of $\mathrm{SiO}_{2}-$ opal, chalcedony and quartz, clay minerals mainly represented by kaolinite, as well as pyrite, siderite, hematite, barite, celestite, gypsum and apatite have been identified (Fig. 1).
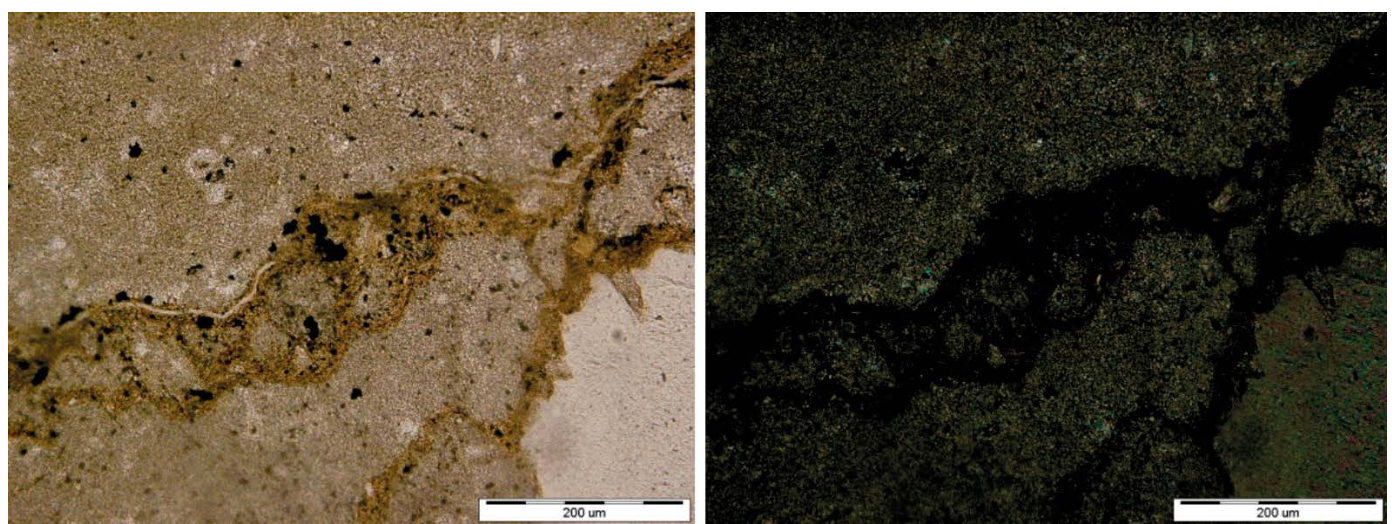

Phot. 4. The limestone from the zone of Mesozoic-Neogene contact in Bełchatów deposit. The stylolite seam filled of lignite. Polarizing microscope; Ip, Xp

Fot. 4. Wapienie ze strefy kontaktu mezozoik-neogen w złożu Bełchatów. Szew stylolitowy wypełniony uwęgloną substancją organiczną. Mikroskop polaryzacyjny; Ip, Xp 


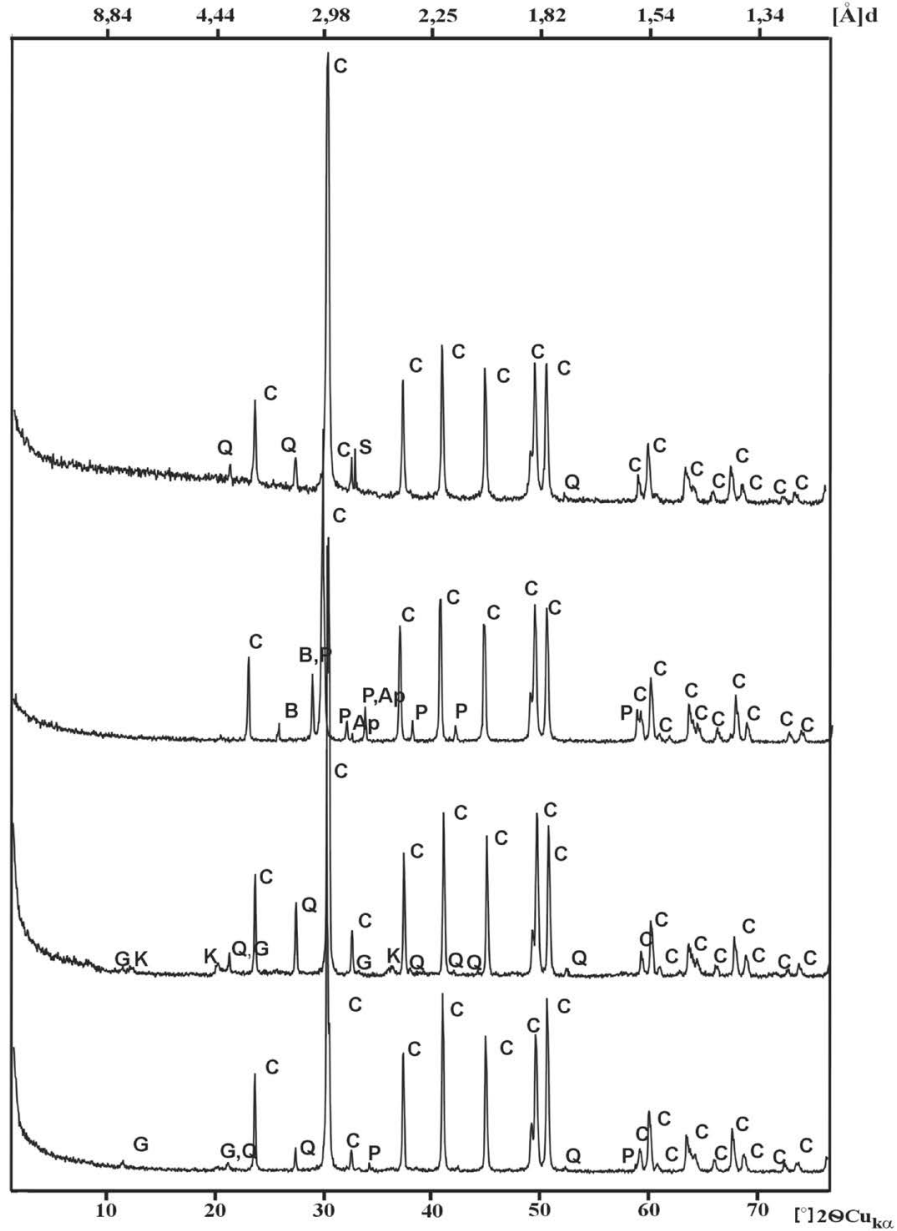

Fig. 1. The phase composition of the limestone from the zone of Mesozoic-Neogene contact in Bełchatów deposit presented at the diffraction patterns

$\mathrm{C}$ - calcite, $\mathrm{P}$ - pyrite, G - gypsum, Q - quartz, S - siderite, B - barite, Ap - apatite, K - kaolinite

Rys. 1. Skład fazowy wapieni ze strefy kontaktu neogen - mezozoik w złożu Bełchatów przedstawiony na dyfraktogramach

C - kalcyt, P - piryt, G - gips, Q - kwarc, S - syderyt, B - baryt, Ap - apatyt, K - kaolinit

Following the complex phase composition of examined limestones also occurs varied chemical composition within the individual samples (Table 1). The content of $\mathrm{CaCO}_{3}$ is included in a wide range from 48.67 to $88.37 \%$ of weights and is on average $70.90 \%$ of the masses. Among other chemical components, the high content of silica reaching even to more than $26 \%$ of masses, as well as iron and aluminum and magnesium and sodium draws attention. Therefore, it is concluded that the tested limestones in most cases do not comply with the requirements for carbonate sorbents used in fluidized furnaces, in which the content of $\mathrm{CaCO}_{3}$ should be at least $85 \%$ of the masses (Lysek 1997). 
Table 1. The chemical composition of the limestone from the contact zone Neogene-Mesozoic in Bełchatów deposit [\% wt.]

Tabela 1. Skład chemiczny wapieni ze strefy kontaktu neogen-mezozoik w złożu Bełchatów [\% mas.]

\begin{tabular}{|l|c|c|c|c|c|c|c|c|c|c|}
\hline Parameter & $\mathrm{SiO}_{2}$ & $\mathrm{TiO}_{2}$ & $\mathrm{Al}_{2} \mathrm{O}_{3}$ & $\mathrm{Fe}_{2} \mathrm{O}_{3}$ & $\mathrm{CaO}$ & $\mathrm{MgO}$ & $\mathrm{MnO}$ & $\mathrm{Na}_{2} \mathrm{O}$ & $\mathrm{K}_{2} \mathrm{O}$ & $\mathrm{P}_{2} \mathrm{O}_{5}$ \\
\hline min. & 7.01 & - & 0.01 & 0.20 & 27.34 & - & 0.014 & 0.02 & 0.01 & 0.01 \\
\hline max. & 26.95 & 0.73 & 7.52 & 11.42 & 49.51 & 4.21 & 0.321 & 3.41 & 0.75 & 0.21 \\
\hline average & 17.34 & 0.08 & 1.76 & 2.76 & 39.83 & 0.53 & 0.060 & 0.52 & 0.10 & 0.07 \\
\hline
\end{tabular}

Explanation: - down to $0.01 \% \mathrm{wt}$.

\subsection{Diagenetic and epigenetic transformations}

The phase and chemical composition, as well as structural and textural features limestones from the Bełchatów deposit (exploitation Field Szczerców) occurring in the contact zone with the Neogene sediments are the result of diagenetic and epigenetic processes. They should be understood as the physical and chemical transformations of sediments ongoing from the moment of sedimentation to the end of lithification (diagenesis) and occurring in rocks already after lithification (epigenesis). The most important are: compaction, cementation, as well as processes of dissolution and recrystallization.

In the tested rocks both the effects of mechanical compaction triggered with pressure of the overburden rocks (blanket rocks), and chemicals associated with the processes of dissolution under pressure have been observed. Mechanical compaction processes already occurred at an early stage of diagenesis. They have led firstly to the reduction of volume, and, thus to increase the density of the sediment. Mechanical compaction occurred in the sediment at least partially without lithification. This is evidenced by the presence of densely packed as well as flattened, and even plastically deformed ooliths (Phot. 5). On the other hand, evidence for the presence of the latter mechanical compaction is the occurrence of cracked grains and bioclasts, fragments of which have been exploded or even displaced relative to each other (Hycnar et al. 2007). Stylolitization and related processes of dissolving rock under pressure also belong to the late diagenetic signs of compaction (Phot. 6). Mechanical pressure in consolidated rock caused the formation of crackings, which then were roads of the migration of solutions and resulted in the dissolution of rocks manifesting itself among others, with incompleteness of grains adhering to stylolite seams (Phot. 6).

At an early stage, diagenesis compaction has been discontinued by cementation, which led to an increase in the stiffness of the sediment. This is indicated by the occurrence of whole, uncrushed skeletal remains in limestones, as well as enclosing over preserved intergranular pores with sparite cement (e.g. in bioomicrites) (Hycnar et al. 2007). At the stage of epigenesis stylolites also ceased to be migration roads of solutions, they were filled with 


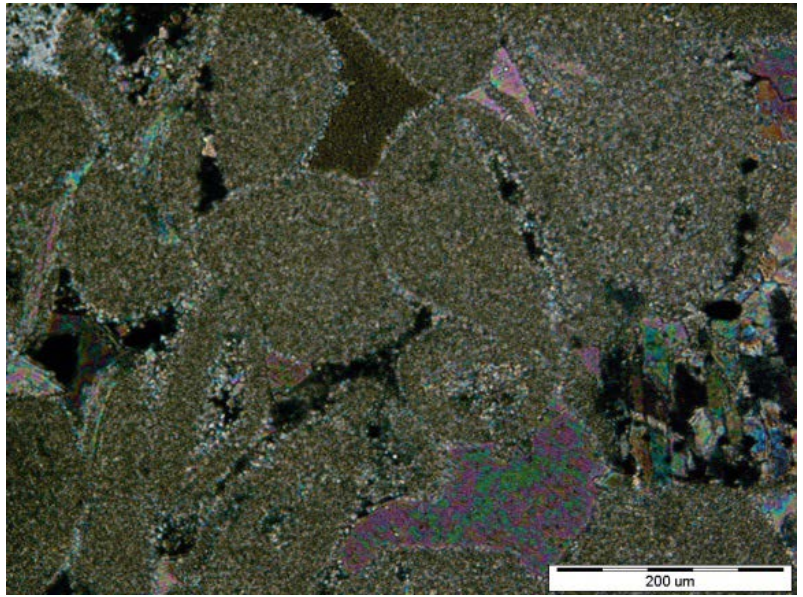

Phot. 5. The limestone from the zone of Mesozoic-Neogene contact in Bełchatów deposit. The deformed ooids. Polarizing microscope, $\mathrm{Xp}$

Fot. 5. Wapienie ze strefy kontaktu mezozoik-neogen w złożu Bełchatów. Zdeformowane ooidy. Mikroskop polaryzacyjny, Xp
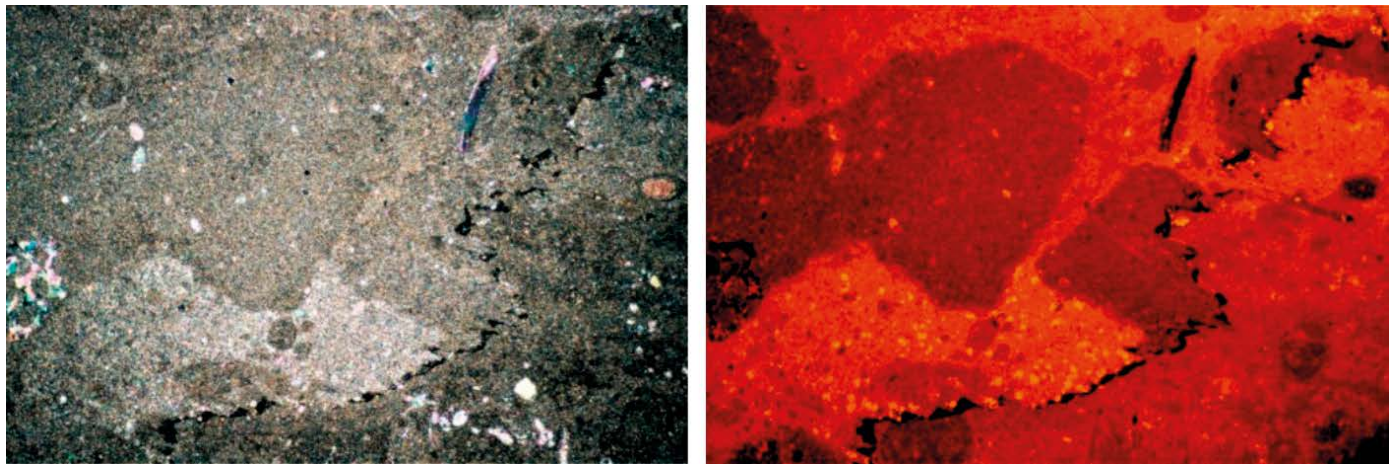

Phot. 6. The limestone from the zone of Mesozoic-Neogene contact in Bełchatów deposit. The dissolved intraclasts at the stylolite seam. Polarizing microscope; Xp, CL image

Fot. 6. Wapienie ze strefy kontaktu mezozoik-neogen w złożu Bełchatów. Rozpuszczone intraklasty na szwie stylolitowym. Mikroskop polaryzacyjny; Xp, CL

an organic substance of vegetable origin (Phot. 4), with pyrite (Phot. 7), as well as carbonate cement and silica.

The most important textural feature of the described rocks is the porosity. It occurs first of all in secondary porosity, having no relationship with the original characteristics of the sediment. The original pores, occurring e.g. inside some bioclasts or created as a result of the activity of living organisms as e.g. hollow forms, channels after infauna in the later stages of diagenesis, have been filled primarily by calcite and also silica minerals or iron 


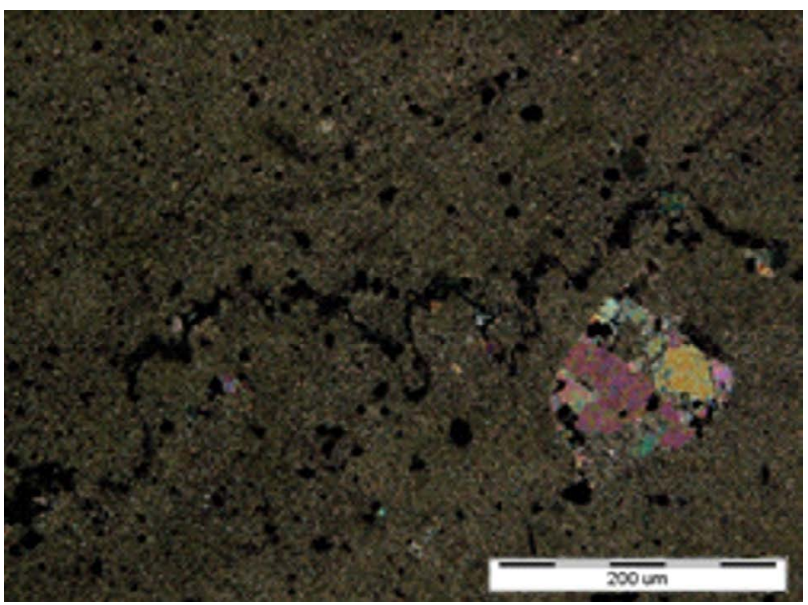

Phot. 7. The limestone from the zone of Mesozoic-Neogene contact in Bełchatów deposit. The stylolite seam filled of pyrite. Polarizing microscope, $\mathrm{Xp}$

Fot. 7. Wapienie ze strefy kontaktu mezozoik-neogen w złożu Bełchatów. Szew stylolitowy wypełniony pirytem. Mikroskop polaryzacyjny, Xp

sulphides. In the case of a limestones from the contact zone, porosity is associated mainly with the karst processes and is also the result of the among-grain dissolution of carbonates (among-grain porosity) and etching of larger mineral grains (inside-grain porosity). Pores associated e.g. with the occurrence of stylolites as well as slits and cracks as a result of mechanical pressure in a consolidated rock in various stages of diagenesis have been partly or even totally built-up (Phot. 3, 4, 7).

\subsection{The mineralisation processes}

Secondary processes of mineralization such as: silicification, pyritization, calcitization are directly related with diagenetic and epigenetic transformations. Sulfatization and phosphating should also be mentioned (Hycnar et al. 2007). Mineralization processes, that occurred under the influence of chemical and biochemical factors are responsible for complex mineral composition of limestones from the contact zone, as they led to the creation of the series of non carbonate mineral phases as well as the younger generation of calcite.

The process commonly occurring within the surveyed limestones is silicification. The enrichment process of rocks in silica has occurred by filling various kinds of pores, stylolite seams, cracks and compaction slits as well as the replacement of calcite e.g. in bioclasts. Under the described appearances silica usually takes on the form of opals (type A or type CT) or chalcedony occasionally takes on the form of microcrystalline quartz. One should combine the silica sources in the silification process with diagenetic processes of Neogene clay rocks occurring within the subcoal series, meaning in the immediate vicinity of the 
bedrocks. Water rich in silica was squeezed from the clays in the mechanical compaction process. A certain amount of silica can also come from the dissolution of plagioclases and from the transformation of terrigenous material, mainly of potassium feldspars grains. Silica precipitation from pore solutions undoubtedly favored the presence of carbonic acid formed as a result of the decomposition of organic substances of vegetable origin. The silicification of formations occurring in the contact zone of bedrocks with Neogene sediments was of primarily a late diagenetic or even epigenetic nature.

Apart from silicification, pyritization is a very well developed mineralization process. Pyrite fills the channels after infauna, stylolite seams, slits and compaction cracks and being the effect of tectonic stresses, as well as rock pores caused by activity of karst solutions. It also commonly replaces calcite in the bioclasts. Under the described appearances, this sulphide adopts different morphological forms starting from amorphous, through framboidal and finishing with crystals with idiomorphic (automorphic) outlines. Diversifying the morphology of pyrites crystal has also been found within framboides themselves. Edifying microframboides takes both oval shapes, and sharp edges with well developed cell walls (Phot. 8). Forms with sharp edges of framboides should be considered as the effect of recrystallisation of oval forms. This phenomenon is possible with the restriction that the slow, undistorted supply of iron and sulfur will be provided during the growth of framboides (Stachura and Ratajczak 2004; Sawłowicz 2000). Therefore framboidal concretions bearing characteristics of recrystallisation can be considered as the older generation of pyrite in

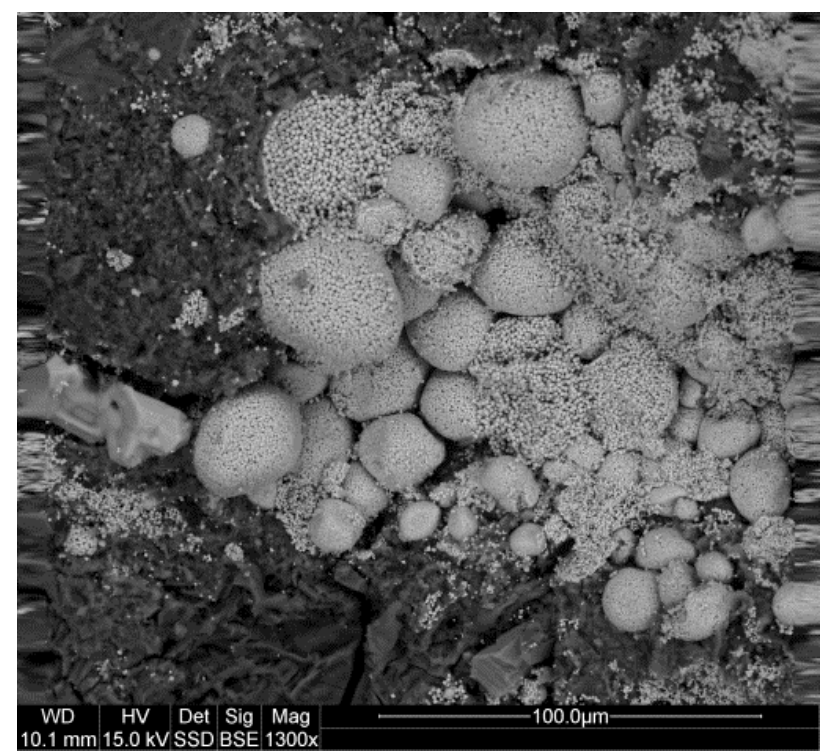

Phot. 8. The limestone from the zone of Mesozoic-Neogene contact in Bełchatów deposit. The pyrite framboids in the pore of rocks. SEM/EDX

Fot. 8. Wapienie ze strefy kontaktu mezozoik-neogen w złożu Bełchatów. Framboidy pirytowe w pustce skalnej. SEM/EDX 
relation to the framboidal forms built from spherical microframboides. The common occurrence of pyrite in the form of framboidal concretions proves that pyritization process, in most cases, are of a biochemical nature. On the other hand, numerous occurrences of pyrite framboidal concretions within stylolite seams or in their immediate vicinity suggests that appropriate pyritization processes occurred during epigenesis and were associated with the decomposition of organic substance of vegetable origin. Prevailing reducing conditions, with the help of microorganisms resulted in the destruction of amino acids leading to the separation of hydrogen sulfide, which subsequently took part in the crystallization of pyrite (Olszewska 1971). Not all forms of the occurrence of pyrite are connected with the activity of microorganisms. Pyrite filling the pores of karst voids, slits and tectonic cracks, as well as replacing calcite in the skeletal elements is the result of crystallization from ionic solutions.

With considerable diversifying the chemical composition and the genesis of formation is also characterized by calcite. In the described sample, rocks form three generations differing from each other in color and luminescence. Calcite that does not have luminescence now exists only in the form of relics in the allogeneic ingredients mainly bioclasts (Phot. 9). Non -luminescent form of calcite should be regarded as the primary, "pure" variation of calcium carbonate formed by the living organisms. It has been replaced by younger generations of calcite (of red and yellow color in the luminescence) at various stages of diagenesis, created as a result of secondary mineralization processes (Phot. 9). Calcite with luminescence of a red color was subject to an influence of diagenetic solutions containing $\mathrm{Fe}^{2+}$ (Sikorska 2005). It can be assumed that this form of calcite was formed at the final stage or shortly after the crystallization of pyrite. Showing a yellow luminescence crystallized under shortage of $\mathrm{Fe}^{2+}$ and with the significant participation of $\mathrm{Mn}^{2+}$ (Sikorska 2005). This form of calcite may be combined with the hypergenical conditions and filtration of groundwaters of meteoric origin. Migration routes of diagenetic solutions, which were the source of crystallization of the youngest calcite generation can also be seen in photograph 9 (image in CL).
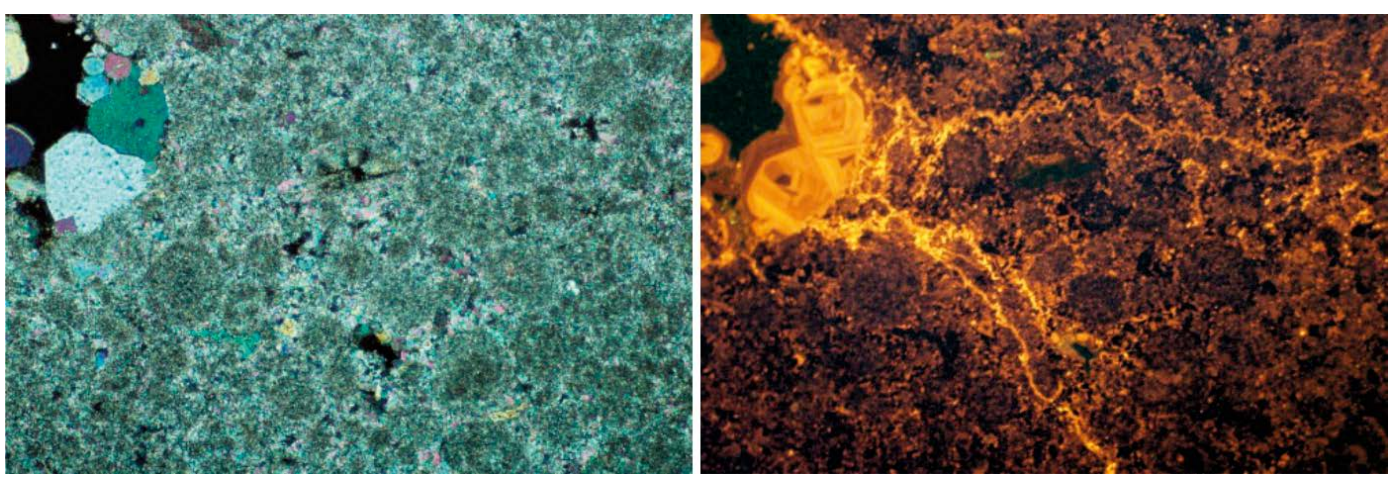

Phot. 9. The limestone from the zone of Mesozoic-Neogene contact in Bełchatów deposit. The generations of calcite with different color in luminescence. Polarizing microscope; Xp, CL

Fot. 9. Wapienie ze strefy kontaktu mezozoik-neogen w złożu Bełchatów. Generacje kalcytu o zróżnicowanej barwie w luminescencji. Mikroskop polaryzacyjny; Xp, CL 
3. The limestones from contact zone as sorbents $\mathrm{SO}_{2}$ in fluidised furnaces

In Poland limestones with a content of $\mathrm{CaCO}_{3}$ above $85 \%$ of masses are used as sorbents $\mathrm{SO}_{2}$ in fluidised furnaces (Lysek 1997; Wisła-Walsh 1997). Sorbent in the form of ground limestone is introduced into the combustion chamber together with fuel. Calcium carbonate $\left(\mathrm{CaCO}_{3}\right)$ contained in limestone in a typical fluidised furnace temperature of $850^{\circ} \mathrm{C}$ undergoes the process of thermic dissociation (decarbonatization) with the creation of $\mathrm{CaO}$ with extensive surface area and porosity and $\mathrm{CO}_{2}$. Subsequently, sulfur dioxide reacts with calcium oxide initially forming calcium (IV) sulfate $\mathrm{CaSO}_{3}$ and then calcium sulfate (VI) $\mathrm{CaSO}_{4}$ calcium sulfide $(\mathrm{CaS})$, which is also is oxidized to calcium sulfate $\left(\mathrm{CaSO}_{4}\right)$ (Antony and Granatstein 2001; Wieczorek-Ciurowa 1995) may also be the intermediate product of sulfation reaction. The sorption of $\mathrm{SO}_{2}$ is on the surface of the pores produced during the decarbonatization process (Chan et al. 1970).

The assessment of sorption capacity in relation to $\mathrm{SO}_{2}$ of the surveyed limestones was carried out according to the guidelines developed by the Ahlstrom Pyropower Development Laboratory (1995). This method is based on the appointment of two indicators: reactivity (RI) and absolute sorption (CI). The reactivity indicator specifies the ratio of calcium content in the sample to the quantity of sulphur after the sorption process [mol $\mathrm{Ca} / \mathrm{mol} \mathrm{S}]$. On the other hand, the absolute sorption CI indicator specifies the sulfur content after sorption by $1000 \mathrm{~g}$ of sorbent [ $\mathrm{g} \mathrm{S} / 1000 \mathrm{~g}$ of sorbent]. $\mathrm{SO}_{2}$ sorption tests of were carried out on the material with a grain size of $0.125-0.250 \mathrm{~mm}$. In accordance with the requirements, before sulfation, the samples were subjected to decarbonatization process in a temperature of $850^{\circ} \mathrm{C}$ in 30 minutes. Subsequently, for a further 30 minutes the gas was passed through samples containing $1780 \mathrm{ppm}$ of $\mathrm{SO}_{2}, 3 \%$ of $\mathrm{O}_{2}$ and $16 \%$ of $\mathrm{CO}_{2}$ at a speed of $950 \mathrm{ml} / \mathrm{sec}$. In the next stage the sulfur content was determined after sorption on the LECO apparatus for elementary analysis. On the basis of the results of research the values of indicators RI and CI have been designated. The assessment of the sorption capacity was performed based on the standard values of the mentioned parameters (Table 2).

Table 2. The reference values reactivity (RI) [mole Ca/mole S] and sorption content (CI) [g S/g sorbent 1000] (Lysek 1997)

Tabela 2. Wartości wzorcowe reaktywności (RI) $[\mathrm{mol} \mathrm{Ca} / \mathrm{mol} \mathrm{S}]$ i sorpcji bezwzględnej (CI) [g S/1000 g sorbentu] (Lysek 1997)

\begin{tabular}{|c|c|c|}
\hline The rating sorption capacity of the sorbent & RI & CI \\
\hline Excellent & $<2.5$ & $>120$ \\
\hline Very good & $2.5-3.0$ & $100-120$ \\
\hline Good & $3.0-4.0$ & $80-100$ \\
\hline Sufficient & $4.0-5.0$ & $60-80$ \\
\hline Low quality & $>5.0$ & $<60$ \\
\hline
\end{tabular}


Research has shown that limestones occurring in the contact zone with Neogene sediments in the Szczerców Field have a sorption properties in respect of $\mathrm{SO}_{2}$ despite the low content of $\mathrm{CaCO}_{3}$, which suggest that these rocks can be utilized in the form of sorbents for lowering the emissions of $\mathrm{SO}_{2}$ in fluidised furnaces. The value of the coefficient of reactivity (RI) remains at the level of 4.47-1.55. On the other hand, the coefficient value of absolute sorption (CI), which determines the sulfur content after sorption by $1000 \mathrm{~g}$ of sorbent $[\mathrm{gS} / 1000 \mathrm{~g}$ of sorbent] is within the range of $62-150$. The presented values of the coefficients allow one to assess the capacity of the sorption of limestones at the level from excellent to sufficient (Hycnar et al. 2007). It should be noted that the unqualified majority of limestones was characterized by the sorption ability at the level of very good, achieving a coefficient of reactivity ca 2.7 , and sorption of approx. 95 . The designated sorption capacity of limestones surveyed is comparable with standard sorbents received from carbonate raw materials.

Structural and textural features, such as the size of calcite crystals and the microporosity had a significant influence on the formation of the sorption properties of the tested limestones in conditions of fluidised furnace. As can be seen on photograph 10, the crystal size is varied within individual grains of sorbent. Larger, sparite calcite crystals are present within the microcrystalline rock matrix.

In photograph 11 the surface of the grains of a sorbent after decarbonatization process is presented. Porosity system expansion and thus increasing the specific surface area of the sorbent able to react with the $\mathrm{SO}_{2}$ has been achieved as a result of the release of $\mathrm{CO}_{2}$ from

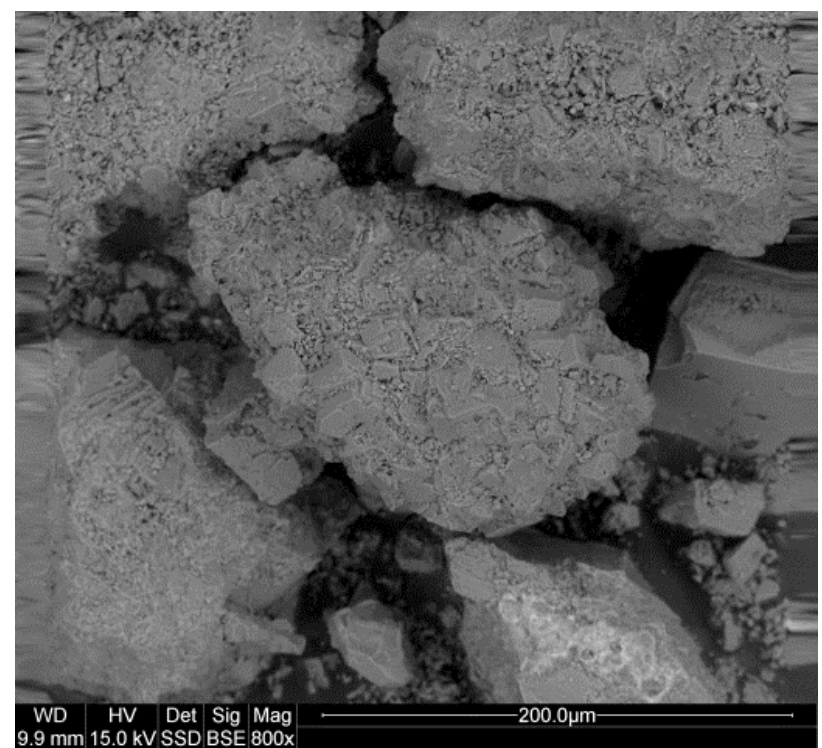

Phot. 10. The limestone from the zone of Mesozoic-Neogene contact in Bełchatów deposit $(0.125-0.250 \mathrm{~mm}$ fraction). The crystals of calcite in the microcrystalline, porous rock background (SEM/EDX)

Fot. 10. Wapienie ze strefy kontaktu mezozoik-neogen w złożu Bełchatów (frakcja 0,125-0,250 mm). Sparytowe kryształy kalcytu w mikrokrystalicznym, porowatym tle skalnym. SEM/EDX 


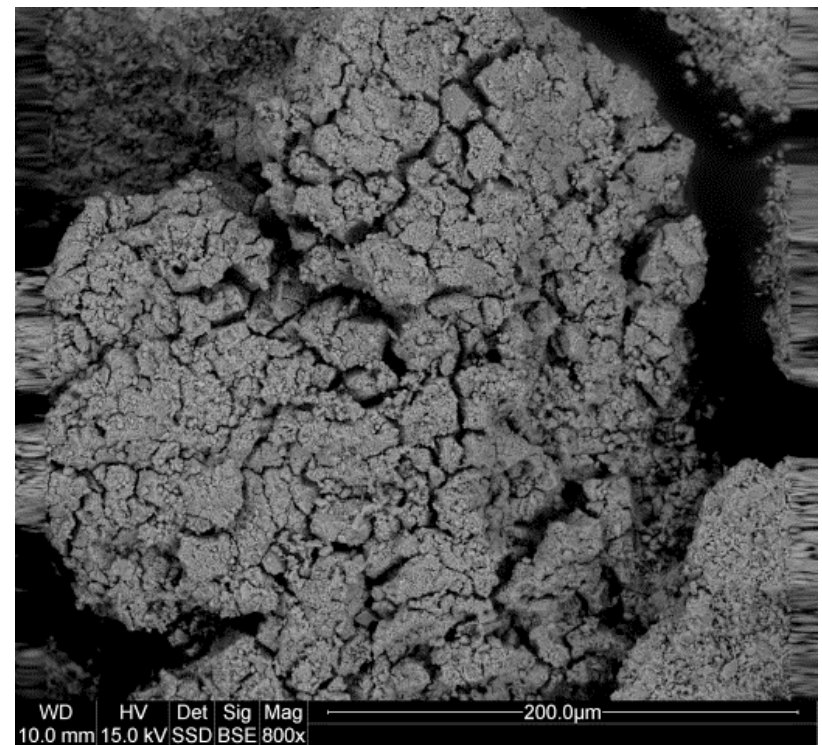

Phot. 11. The limestone from the zone of Mesozoic-Neogene contact in Bełchatów deposit $(0.125-0.250 \mathrm{~mm}$ fraction). The grain surface after the calcinations process, the cracks on it (SEM/EDX)

Fot. 11. Wapienie ze strefy kontaktu mezozoik-neogen w złożu Bełchatów (frakcja 0,125-0,250 mm) Powierzchnia ziarna po procesie dekarbonatyzacji, widoczne pęknięcia (SEM/EDX)

the calcite structures. Crevices and cracks created within large calcite crystals have played an important role in this case. During the thermal dissociation of calcite, they perform the function of rapid roads of diffusion of $\mathrm{CO}_{2}$ from the structure of calcite (Boyton 1966; Lech 2011). The decarbonatization process also includes the interior of sorbent grain with their presence. In this manner, the sorption of $\mathrm{SO}_{2}$ occurs not only on the surface of the grains of sorbent after decarbonatization, but also reaches into the deeper layers. $\mathrm{SO}_{2}$ particles penetrate into the interior of sorbent grains through the diffusion channels and are sorbed also on the the inner surface after decarbonatization. Grains of sorbent, which generated cracks during decarbonatization process (Phot. 11) were characterized by a significantly higher assessment of reactivity as compared to the grains in which of this type of slits are not generated (Phot. 12). In the event that there is no manufacture of cracks, the $\mathrm{SO}_{2}$ sorption process takes place on surface of sorbent grains, which is coated with a layer forming a sulphate. As a result, the sorption of $\mathrm{SO}_{2}$ is locked in the initial stage of the process.

In real conditions prevailing in the circulating fluidised furnaces are exposed its next unreacted layers, which after the process of decarbonatization will be able to adopt new portions of $\mathrm{SO}_{2}$ as a result of attrition of reacted covered with the products of surface desulphurization of sorbent. However, in this case both the process of decarbonatization and sorption run less efficiently and there is a slow uptake of $\mathrm{SO}_{2}$.

It seems therefore that tectonic discontinuities and compaction crevices and cracks have played an important role in the formation of depicted on the photograph 11 of diffusion 


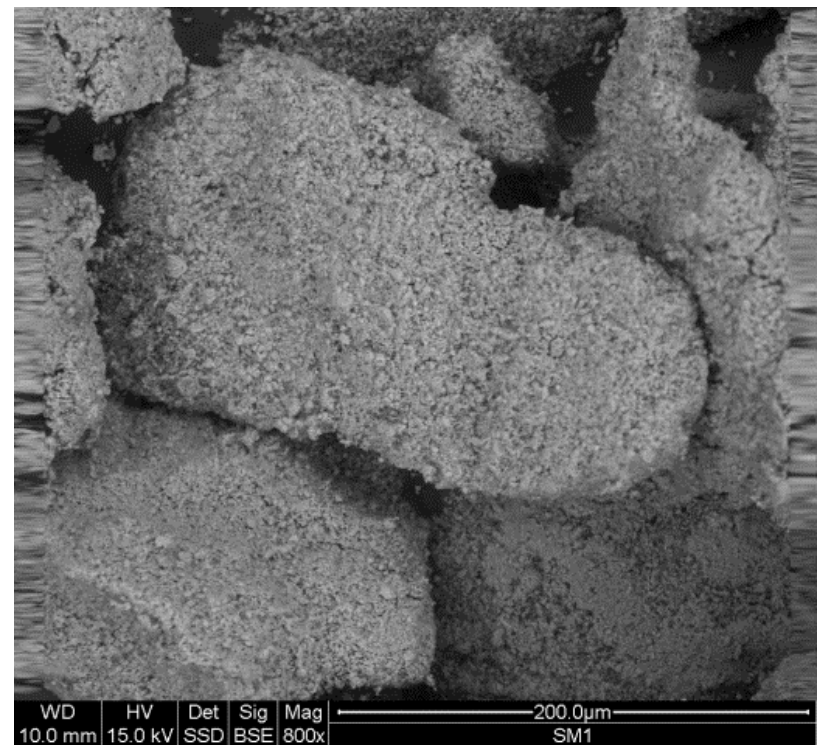

Phot. 12. The limestone from the zone of Mesozoic-Neogene contact in Bełchatów deposit $(0.125-0.250 \mathrm{~mm}$ fraction). The grain surface after the calcinations process, lack of cracks (SEM/EDX)

Fot. 12. Wapienie ze strefy kontaktu mezozoik-neogen w złożu Bełchatów (frakcja 0,125-0,250 mm) Powierzchnia ziarna po procesie dekarbonatyzacji, brak pęknięć (SEM/EDX)

channels of $\mathrm{SO}_{2}$. Forms of this type were, as a rule, filled by the organic substance after coalification of vegetable origin or by iron sulfides. These fillings do not hinder the course of decarbonatization process because their thermal decomposition ends in a decidedly lower temperatures than calcite. In addition, iron oxides resulting from the decomposition of pyrite catalyze the oxidation reactions of $\mathrm{SO}_{2}$ to $\mathrm{SO}_{3}$ (Schroeder and Grzesiak ed. 2011). On the other hand, $\mathrm{SO}_{3}$ particles interact more effectively with $\mathrm{CaO}$ intensifying the desulfurization process (Antony and Granatstein 2001).

\section{Conclusions}

Limestones, occurring in the Neogene sediments contact zone with rocks of Mesozoic substrate in the Bełchatów deposit (Szczerców Fieldexploitation), although does not meet quality requirements, have a chance to use in the form of sorbents for lowering the emissions of $\mathrm{SO}_{2}$ in fluidized furnaces. A significant influence on the sorption properties of limestones, apart from the content of $\mathrm{CaCO}_{3}$, influences the structural and textural nature of rocks.

The structure and texture of the surveyed limestones have been shaped at the stage of diagenesis and epigenesis, through the processes of dissolution and recrystallization of calcite occur under varying environmental conditions. Sparite calcite crystals have played 
the most important role in shaping the sorption capacity of limestones . Within them, during the process of decarbonization, the cracks formed. They carry out the function of both channels of rapid diffusion of $\mathrm{CO}_{2}$ from the calcite structure, as well as $\mathrm{SO}_{2}$ migration routes to the interior of the grains of a sorbent. As a result, the $\mathrm{SO}_{2}$ sorption process is not only on the surface of the grains of a sorbent, but also includes their interior. These types of crevices and cracks arise only within the sparite calcite crystals. They are not created within calcite micrite. During the heating of the sorbent grains in the initial phase of decarbonatization process, increasing the volume of the grain, and then its shrinkage takes place first (Boyton 1966; Lech 2011). This change of stresses causes cracks within sparite calcite crystals.

The porosity of microcrystalline rock matrix, which also occurred as a result of diagenetic and epigenetic processes is also of vital significance in shaping the sorption capacity of the tested limestones. Pores between micrite or calcitic microsparite crystals both accelerate the decarbonatization of rock matrix process, and increase its range in the deeper layers of sorbent grains, which led to increasing the effectiveness of the uptake of $\mathrm{SO}_{2}$.

The presence in limestones of other non carbonate mineral components such as pyrite or organic substance after carbonification of vegetable origin is also a beneficial parameter from the point of view of the desulphurisation process effectiveness.

Sorption properties of limestones in respect of $\mathrm{SO}_{2}$ in conditions of a fluidised furnace do not depend in direct proportion on the content of $\mathrm{CaCO}_{3}$. The reactivity of limestones and bonding ability of $\mathrm{SO}_{2}$ increases with the expansion of porosity and the increase of a specific surface area during the thermal decomposition of sorbent.

The work is statutory activities of the Department of Mineralogy, Petrography and Geochemistry of the AGH University of Science and Technology in Cracow in 2015 (No. 11.11.140.319)

\section{REFERENCES}

Adamczyk et al. 2012 - Adamczyk, K., Jończyk, M. and Skórzak, A. 2012. Wapienie w kopalni węgla brunatnego Bełchatów. Górnictwo Odkrywkowe R. 53, Nr 1-2, pp. 47-54 (in Polish).

Anthony, E.J. and Granatstein, D.L. 2001. Sulfation phenomena in fluidized bed combustion systems. Progress in Energy and Combustion Science 27, pp. 215-236.

Alsthrom Pyropower Reactivity index. Alsthrom Pyropower 1995.

Smakowski et al. ed. 2014 - Smakowski, T., Ney, R. and Galos, K. 2014. Bilans gospodarki surowcami mineralnymi Polski i Świata 2012. Wydawnictwo IGSMiE PAN, Warszawa, 1171 pp. (in Polish).

Boynton, R.S., 1966. Chemistry and technology of lime and limestone. John Wiley and Sons Inc.; New York, London, Sydney, pp. 132-164.

Chan et al. 1970 - Chan, R.K., Murthai, K.S. and Harrison, D. 1970. Thermogravimetric analysis of Ontario limestones and dolomites. II. Reactivity of sulfur dioxide with calcined samples. Canadian Journal of Chemistry 48, pp. 2979-2982.

Dodatek 1989 - Dodatek do Kompleksowej Dokumentacji Geologicznej Złoża Węgla Brunatnego Betchatów - Pole Szczerców w kat.C1 + B. Czesść geologiczno-inżynierska. Przedsiębiorstwo Geologiczne we Wrocławiu, styczeń 1989 (in Polish). 
Dodatek nr 11989 -Dodateknr 1 do Kompleksowej Dokumentacji Geologicznej złoża węgla brunatnego Bełchatów Pole Bełchatów w kategorii C1 + B. Przedsiębiorstwo Geologiczne we Wrocławiu, Wrocław, czerwiec 1989 (in Polish).

Dodatek w kat B 1975 - Dodatek w kat. B do Kompleksowej Dokumentacji Geologicznej Złoża Węgla Brunatnego Betchatów - Pole Betchatów w kat.C1 + B (rejon wkopu) z 1964 r. Przedsiębiorstwo Geologiczne we Wrocławiu, Wrocław 1975 (in Polish).

Dokumentacja Geologiczna Złoża Węgla Brunatnego Bełchatów w kat.C1 + B (rejon wkopu). Przedsiębiorstwo Geologiczne we Wrocławiu, Wrocław 1964 (in Polish).

Hycnar et al. 2007 - Hycnar, E., Gilarska, A., Wisła-Walsh, E., Zych, Ł. and Sikorska, M. 2007. Wapienie ze strefy kontaktu trzeciorzęd - mezozoik w złożu węgla brunatnego Bełchatów i możliwości ich wykorzystania jako sorbentów do obniżania emisji $\mathrm{SO}_{2}$. Górnictwo Odkrywkowe R. 49, Nr 7, pp. 30-36 (in Polish).

Kompleksowa Dokumentacja Geologiczna złoża węgla brunatnego Bełchatów w kat. C1 + B - Pole Szczerców. Kombinat Geologiczny „Zachód”, Zakład Projektów i Dokumentacji Geologicznych, Wrocław, czerwiec 1977 (in Polish).

Kompleksowa Dokumentacja Geologiczna Złoża Węgla Brunatnego Bełchatów - Pole Bełchatów w kategorii C1 + B, Przedsiębiorstwo Geologiczne we Wrocławiu. Wrocław czerwiec 1983 (in Polish).

Lech, R. 2011. Właściwości wapieni i produktu ich dysocjacji termicznej. Część I. Wapienie. Cement, Wapno, Beton Nr 3, pp. 148-160 (in Polish).

Lysek, N. 1971. Sorbenty do odsiarczania gazów. Produkcja i zastosowanie. Opolwap S.A., Tarnów Opolski, 156 p. Olszewska, M. 1971. Cytologia roślin. Warszawa, PWN, 586 pp. (in Polish).

Pole Bełchatów. Ocena stopnia zagrożenia oraz wytyczne do prowadzenia skarp stałych zbocza poludniowego 0/-110 m n.p.m. między liniami 63SN-55SN - etap VII. Biuro Projektów Górniczych i Geologicznych PROGiG Sp. z o. o.Wrocław, 2011 (in Polish).

Pole Szczerców. Aktualizacja konturu zboczy stałych wyrobiska od zbocza tymczasowo-stałego do końca eksploatacji. Poltegor - Projekt Sp. z o.o., Wrocław, czerwiec 2009 (in Polish).

Pole Szczerców. Aktualizacja konturu zboczy statych wyrobiska od zbocza tymczasowo-statego do końca eksploatacji. Poltegor - Projekt Sp. z o.o. Wrocław, czerwiec 2009 (in Polish).

Sawłowicz, Z. 2000. Framboids: from their origin to applictaion. Prace Mineralogiczne t. 88. Wydawnictwo Oddziału Polskiej Akademii Nauk, 80 pp.

Sikorska, M. 2005. Badania katodoluminescencyjne minerałów. Wydawnictwo Państwowego Instytutu Geologicznego, Warszawa, pp. 1-64 (in Polish).

Stachura, E. and Ratajczak, T. 2004. The origin of pyrite in Miocene lignite from the Bełchatów deposit. Prace Specjalne, Polskie Towarzystwo Mineralogiczne z. 24 pp. 361-364.

Wieczorek-Ciurowa, K. 1995. Analysis, Catalytic sulphation of limetstone/lime with platinum: a thermal analysis study. Journal of Thermal 38, pp. 2101-7.

Wisła-Walsh, E. 1997. Nowoczesne metody odsiarczania gazów odlotowych. Materiały II ogólnopolskiej konferencji naukowo-technicznej pt. „Sorbenty do odsiarczania spalin”, Kamień Śląski (in Polish).

Schroeder, G. and Grzesiak, P., ed. 2011. Środowisko i przemyst. Tom II. Wydawnictwo Cursiva, 200 pp. (in Polish). 


\title{
CHARAKTER STRUKTURALNO-TEKSTURALNY A WLAŚCIWOŚCI SORPCYJNE WAPIENI ZE STREFY KONTAKTU MEZOZOIK-NEOGEN W ZLOŻU BELCHATÓW
}

\author{
Słowa kluczowe \\ sorbenty $\mathrm{SO}_{2}$, technologia spalania fluidalnego, \\ współczynniki reaktywności (RI) i sorpcji bezwględnej (CI)
}

\section{Streszczenie}

Jedną najważniejszych kopalin towarzyszących w złożu węgla brunatnego Bełchatów są wapienie wieku jurajskiego. Wchodzą one w skład kompleksu skał podłoża oraz budują zbocza pól eksploatacyjnych Bełchatów i Szczerców gdzie na skutek postępujące eksploatacji węgla są sukcesywnie odsłaniane. Do tej pory w KWB Bełchatów wydobyto prawie $2 \mathrm{mln}$ ton wapieni, które wykorzystano w formie kruszywa drogowego. Do wydobycia pozostało około $2 \mathrm{mln}$ ton w polu Bełchatów i od 20 do prawie $70 \mathrm{mln}$ ton w polu Szczerców. Wapienie występujące w złożu Bełchatów są zróżnicowane jakościowo. Te znajdujące się w bezpośrednim kontakcie z osadami neogeńskimi charakteryzują się silnym skrasowieniem, a nawet występowaniem w formie zwietrzelin. Ponadto objęte są procesami wtórnej mineralizacji. Procesy te spowodowały znaczne urozmaicenie składu mineralnego i chemicznego, a tym samym przyczyniły się do obniżenia zawartości $\mathrm{CaCO}_{3}$. Pomimo tego wapienie ze strefy kontaktu mezozoik-neogen posiadają znakomite właściwości sorpcyjne względem $\mathrm{SO}_{2} \mathrm{w}$ warunkach palenisk fluidalnych. Właściwości te są determinowane przede wszystkim ich charakterem strukturalno-teksturalnym, a zwłaszcza obecnością sparytowych kryształów kalcytu w mikrokrystalicznym tle skalnym, mikroporów, nieciągłości tektonicznych, spękań i szczelin kompakcyjnych. Dzięki ich obecności procesy zarówno dekarbonatyzacji, jak i sorpcji przebiegają efektywnie. Cząstki $\mathrm{CO}_{2}$ są szybko usuwane ze struktur kryształów kalcytu, a $\mathrm{SO}_{2}$ są w stanie przeniknąć do wnętrza ziaren sorbentu, gdzie są adsorbowane na powierzchni wewnętrznej porów powstałych w wyniku procesu dekrabonatyzacji. Te charakterystyczne właściwości strukturalne i teksturalne badanych wapieni zostały ukształtowane na etapie diagenezy i epigenezy. Przyczyniły się do tego przede wszystkim procesy kompakcji mechanicznej i chemicznej, cementacji, a także procesy rozpuszczania i rekrystalizacji. Pomimo niskiej zawartości $\mathrm{CaCO}_{3}$ wapienie ze strefy kontaktu mezozoik-neogen z powodzeniem mogą być wykorzystywane w formie sorbentów do ograniczania emisji $\mathrm{SO}_{2} \mathrm{w}$ warunkach palenisk fluidalnych. 


\title{
STRUCTURAL-TEXTURAL NATURE AND SORPTION PROPERTIES OF LIMESTONES
} FROM THE MESOZOIC-NEOGENE CONTACT ZONE IN THE BELCHATÓW DEPOSIT

\author{
Keywords \\ $\mathrm{SO}_{2}$ sorbents, fluidised furnaces, indicators reactivity (RI) and absolute sorption (CI)
}

Abstract

Limestones of the Jurassic age are one of the most important minerals accompanying the Be1chatówlignite deposits. They are part of the Bełchatów and Szczerców rock subsoil complex and form natural hillsides of exploitation fields, which are gradually being exposed due to the progressive exploitation of coal. So far in Bełchatów Lignite Mine nearly 2 million tonnes of limestones have been extracted, which were used in the form of highway aggregate. For the extraction (mineral recovery) approx. 2 million tonnes remained in the Bełchatów field and from 20 to nearly 70 million tonnes in the Szczerców field. The limestones occurring in the deposit Bełchatów are differential qualitatively. Those situated in direct contact with Neogene deposits are characterized by strong karstification (karst formation), and even occur in the form of detrital minerals. Furthermore, they are covered by processes of secondary mineralization. These processes caused significant diversity of phase and chemical composition, and thereby have contributed to reducing the $\mathrm{CaCO}_{3}$ content. Despite this, limestones from the Mesozoic-Neogene contact zone possess excellent sorption properties in respect of $\mathrm{SO}_{2}$ in conditions of fluidised furnaces. These properties are determined firstly by their structural-textural nature, and above all with the presence of calcite sparite crystals in microcrystalline groundmass, of micropores, tectonic discontinuities, fracturings and compaction slits. With their presence, both decarbonatization and sorption processes proceed effectively. The $\mathrm{CO}_{2}$ particles are quickly removed from the structures of calcite crystals, and $\mathrm{SO}_{2}$ is able to penetrate into the interior of the sorbent grains where are absorbed on the inner surface of pores arising as a result of the decarbonatization process. These characteristic structural and textural properties of the surveyed limestones have been shaped at the diagenesis and epigenesis stage. This contributed to all chemical and mechanical compaction and cementation processes, as well as the dissolution and recrystallization processes. Despite the low $\mathrm{CaCO}_{3}$ content limestones from the Mesozoic-Neogene contact zone can be successfully used in the form of sorbents to reduce $\mathrm{SO}_{2}$ emissions in conditions of fluidised furnaces. 
